\title{
Intraspecific and Intergeneric Mobilization of Non-conjugative Resistance Plasmids by a 24.5 Megadalton Conjugative Plasmid of Neisseria gonorrhoeae
}

\author{
By FIONA FLETT, $\dagger$ G. O. HUMPHREYS AND J. R. SAUNDERS* \\ Department of Microbiology, University of Liverpool, P.O. Box 147, \\ LiverDool L69 3BX, U.K.
}

(Received 11 December 1980)

\begin{abstract}
pLE2451, a 24.5 megadalton conjugative plasmid from Neisseria gonorrhoeae, was capable of efficiently mobilizing gonococcal $\beta$-lactamase plasmids between gonococci and from gonococci to Haemophilus influenzae and restriction-deficient Escherichia coli. Donor strains of $N$. gonorrhoeae carrying pLE2451 were also found to be capable of mobilizing a variety of non-conjugative plasmids originally derived from enteric bacteria or Haemophilus species when such plasmids were resident in $E$. coli. Nevertheless, pLE2451 was not detected physically in $E$. coli or $H$. influenzae transconjugants. This suggests that the plasmid is unstable in these hosts but survives transiently to provide transfer functions for mobilization. The proficiency of pLE2451 in promoting intraspecific and intergeneric mobilization was not paralleled by pUB701, pRI234 and pFR16017, a series of conjugative plasmids derived originally from Haemophilus species. These plasmids were incapable of mobilizing even Haemophilus $\beta$-lactamase plasmids, such as RSF0885, between Haemophilus species.
\end{abstract}

\section{INTRODUCTION}

Penicillin-resistant strains of Neisseria gonorrhoeae that produce the TEM $\beta$-lactamase contain non-conjugative plasmids of either 4.4 or 3.2 megadaltons (Elwell et al., $1977 a$; Roberts et al., 1977). The vast majority of gonococcal isolates, whether or not they carry $\beta$-lactamase plasmids, contain a 2.6 megadalton multicopy plasmid of unknown function (Davies \& Normark, 1980; Mayer et al., 1974; Roberts et al., 1979). In addition, many strains of $N$. gonorrhoeae, isolated from diverse geographical locations, carry larger conjugative plasmids of about 24.5 megadaltons (Roberts et al., 1979; Sox et al., 1978; Tenover et al., 1980). These large plasmids form a group of closely related DNA molecules sharing a common core sequence of 70 to $100 \%$ (Roberts et al., 1979). They have been referred to as gonococcal sex factors and are capable of mobilizing the 4.4 megadalton $\beta$-lactamase plasmid to other gonococci, to Neisseria flava and to restriction-deficient Escherichia coli (Eisenstein et al., 1977; Roberts \& Falkow, 1977; Sox et al., 1978).

Molecular studies have indicated that the $\beta$-lactamase plasmids of $N$. gonorrhoeae are related in base sequence to small $\beta$-lactamase plasmids isolated from Haemophilus influenzae (Laufs et al., 1979), Haemophilus parainfluenzae (Roberts et al., 1977) and Haemophilus ducreyi (Brunton et al., 1979). This has prompted speculation that $N$. gonorrhoeae may have acquired its $\beta$-lactamase plasmids by genetic transfer of plasmids already existing in the Haemophilus gene pool (Laufs et al., 1979; Roberts et al., 1977; Sparling et al., 1978). In an attempt to understand the routes by which gonococcal resistance plasmids may have evolved

† Present address: Department of Biochemistry, University of Manchester Institute of Science and Technology, Manchester M60 1QD, U.K. 
we have investigated the ability of the 24.5 megadalton plasmid pLE2451 (Elwell \& Falkow, 1977) to mobilize a variety of non-conjugative plasmids in intraspecific and intergeneric matings.

\section{METHODS}

Bacterial strains and plasmids. The bacterial strains and plasmids used are shown in Table 1.

Antibiotics. Ampicillin and carbenicillin were gifts of Beecham Pharmaceuticals, Brockham Park, Surrey. Tetracycline and chromogenic cephalosporin 87/312 were gifts of Glaxo Research Ltd, Greenford, Middx. All other antibiotics were obtained from Sigma.

Media and growth conditions. Neisseria gonorrhoeae and Haemophilus influenzae were routinely grown in an atmosphere of 5-10\% (v/v) $\mathrm{CO}_{2}$ at $37^{\circ} \mathrm{C}$ on chocolate agar prepared from Columbia Agar Base (Oxoid) and $10 \%(\mathrm{v} / \mathrm{v})$ horse blood. This medium was supplemented when required with rifampin $\left(5 \mu \mathrm{g} \mathrm{ml}^{-1}\right)$, nalidixic acid

\section{Table 1. Bacterial strains and their plasmids}

\begin{tabular}{|c|c|c|c|c|c|}
\hline Strain & $\begin{array}{l}\text { Chromosomal } \\
\text { markers* }\end{array}$ & $\begin{array}{c}\text { Plasmid } \\
\text { designation }\end{array}$ & $\begin{array}{c}\text { Mol. mass } \\
\text { (megadalton) }\end{array}$ & $\begin{array}{c}\text { Resistance } \\
\text { pattern } \dagger\end{array}$ & Reference/source \\
\hline $\begin{array}{l}\text { N. gonorrhoeae } \\
\text { 1L261 }\end{array}$ & - & $\underline{\mathrm{pLV} 11}$ & $\begin{array}{l}3 \cdot 2 \\
2 \cdot 6\end{array}$ & $\underline{\text { Ap }}$ & $\begin{array}{l}\text { This study; Royal } \\
\text { Liverpool Infirmary }\end{array}$ \\
\hline $\begin{array}{l}\text { N. gonorrhoeae } \\
\text { 1L432 }\end{array}$ & - & pLV 10 & $\begin{array}{r}24 \cdot 5 \\
4 \cdot 4 \\
2 \cdot 6\end{array}$ & $\overline{\text { Ap }}$ & $\begin{array}{l}\text { This study; Royal } \\
\text { Liverpool Infirmary }\end{array}$ \\
\hline $\begin{array}{l}\text { N. gonorrhoeae } \\
1 \mathrm{~L} 433\end{array}$ & - & $\underline{\mathrm{pLV} 12}$ & $\begin{array}{l}4 \cdot 4 \\
2 \cdot 6\end{array}$ & $\underline{\text { Ap }}$ & $\begin{array}{l}\text { This study; Royal } \\
\text { Liverpool Infirmary }\end{array}$ \\
\hline $\begin{array}{l}\text { N. gonorrhoeae } \\
\text { KH45 }\end{array}$ & - & pLE2451 & $24 \cdot 5$ & - & $\begin{array}{l}\text { Elwell \& Falkow } \\
\text { (1977) }\end{array}$ \\
\hline $\begin{array}{l}\text { N. gonorrhoeae } \\
\text { lL403 }\end{array}$ & $\operatorname{Rif}^{r} \mathrm{Nal}^{r}$ & - & $2 \cdot 6$ & - & This study \\
\hline $\begin{array}{l}\text { H. influenzae } \\
\text { UB2806 }\end{array}$ & $\operatorname{Str}^{r}$ & - & - & - & $\begin{array}{l}\text { Saunders et al. } \\
\text { (1978) }\end{array}$ \\
\hline $\begin{array}{l}\text { H. influenzae } \\
\text { UB2808 }\end{array}$ & $\operatorname{Str}^{r} \mathrm{Nal}^{r}$ & 一 & 一 & - & $\begin{array}{l}\mathrm{Nal}^{\mathrm{r}} \text { derivative of } \\
\text { UB2806 }\end{array}$ \\
\hline $\begin{array}{l}\text { H. influenzae } \\
\text { FR16017 }\end{array}$ & 一 & pFR 16017 & 33 & Tc & Kaulfers et al. (1978) \\
\hline $\begin{array}{l}\text { H. influenzae } \\
\text { UB2811 }\end{array}$ & - & pUB701 & 31 & Tc & Elwell et al. $(1977 b)$ \\
\hline $\begin{array}{l}\text { H. influenzae } \\
\mathrm{HC} 234\end{array}$ & 一 & pRI234 & 38 & $\mathrm{Cm} \mathrm{Tc}$ & $\begin{array}{l}\text { van Klingeren et al. } \\
\text { (1977) }\end{array}$ \\
\hline $\begin{array}{l}E . \text { coli } \\
\text { KH802 }\end{array}$ & $\begin{array}{l}r p o B \\
h s d R_{\mathrm{k}}-M_{\mathrm{k}}^{+}\end{array}$ & - & - & - & Wood (1966) \\
\hline $\begin{array}{l}\text { E. coli } \\
\text { UB } 1005\end{array}$ & met nalA & - & - & - & Grinsted et al. (1972) \\
\hline $\begin{array}{l}E . \text { coli } \\
\text { J53(RSF0885) }\end{array}$ & met pro nalA & RSF0885 & $4 \cdot 1$ & Ap & Roberts et al. (1977) \\
\hline $\begin{array}{l}E . \text { coli } \\
\text { J53(pJB 1) }\end{array}$ & met pro nalA & $\mathrm{pJB} 1$ & $6 \cdot 0$ & Ap & Brunton et al. (1979) \\
\hline $\begin{array}{r}\text { E. coli } \\
1 \mathrm{~L} 40\end{array}$ & - & NTP1 & $5 \cdot 6$ & Ap & Smith et al. (1974) \\
\hline $\begin{array}{r}\text { E. coli } \\
\text { IL44 }\end{array}$ & nalA & NTP5 & $6 \cdot 5$ & $\mathrm{Tc}$ & Smith et al. (1974) \\
\hline $\begin{array}{l}\text { E. coli } \\
\text { 1L190 }\end{array}$ & strA & NTP16 & $5 \cdot 7$ & $\mathrm{Ap} \mathrm{Km}$ & $\begin{array}{l}\text { Anderson et al. } \\
\quad(1977)\end{array}$ \\
\hline $\begin{array}{l}\text { E. coli } \\
\text { C600(ColE1.Tn501) }\end{array}$ & - & ColE1.Tn501 & $10 \cdot 2$ & $\mathbf{H g}$ & P. M. Bennett \\
\hline
\end{tabular}

This study; Royal

This study; Royal

Liverpool Infirmary

This study; Royal

Liverpool Infirmary

Elwell \& Falkow

(1977)

Saunders et al.

(1978)

$\mathrm{Nal}^{\mathrm{r}}$ derivative of UB2806

Elwell et al. (1977b)

an Klingeren et al.

(1977)

Roberts et al. (1977)

Brunton et al. (1979)

Smith et al. (1974)

Smith et al. (1974)

Anderson et al.

(1977)

P. M. Bennett

\footnotetext{
$\dagger$ Resistance to: Ap, ampicillin; Tc, tetracycline; $\mathrm{Cm}$, chloramphenicol; $\mathrm{Km}$, kanamycin; $\mathrm{Hg}$, mercury.
} 
$\left(2 \mu \mathrm{g} \mathrm{m}^{-1}\right)$ or penicillin $\mathrm{G}\left(5 \mu \mathrm{g} \mathrm{m}^{-1}\right)$ for gonococci and with streptomycin $\left(50 \mu \mathrm{g} \mathrm{ml}^{-1}\right)$, nalidixic acid $\left(5 \mu \mathrm{g} \mathrm{m}^{-1}\right)$, ampicillin $\left(10 \mu \mathrm{g} \mathrm{ml}^{-1}\right)$ or tetracycline $\left(4 \mu \mathrm{g} \mathrm{m}^{-1}\right)$ for Haemophilus strains. Escherichia coli strains were grown in nutrient broth or on nutrient agar at $37^{\circ} \mathrm{C}$. The medium was supplemented with rifampin $\left(100 \mu \mathrm{g} \mathrm{m}^{-1}\right)$, nalidixic acid $\left(20 \mu \mathrm{g} \mathrm{ml}^{-1}\right)$, tetracycline $\left(10 \mu \mathrm{g} \mathrm{ml}^{-1}\right), \mathrm{HgCl}_{2}\left(15 \mu \mathrm{g} \mathrm{ml}^{-1}\right)$ or ampicillin $(50 \mu \mathrm{g} \mathrm{ml}$ for resistance selection. In certain triparental matings, e.g. $N$. gonorrhoeae $\times E$. coli $(\mathrm{pLV} 10) \times E$. coli, ampicillin $\left(250 \mu \mathrm{g} \mathrm{ml}^{-1}\right)$ or carbenicillin $\left(250 \mu \mathrm{g} \mathrm{ml}^{-1}\right)$ was incorporated in the medium selective for transconjugants. These high antibiotic concentrations were required to overcome the problem of background growth resulting fiom the $\beta$-lactamase activity of the intermediate donor.

Agarose gel electrophoresis of plasmid DNA. Cleared lysates of bacterial cultures were prepared and subjected to electrophoresis through $1 \%(\mathrm{w} / \mathrm{v})$ agarose gels essentially as described by Meyers et al. (1976).

Transformation of E. coli. Escherichia coli strains were transformed with plasmid DNA as described previously (Brown et al., 1979).

Conjugation. Biparental mațings were performed by mixing donor and recipient strains $\left(10^{8}\right.$ colony-forming units $\mathrm{ml}^{-1}$ ) on $0.45 \mu \mathrm{m}$ pore-size nitrocellulose filters (Oxoid Nuflow) and incubating the filters on the surface of chocolate agar plates for $18 \mathrm{~h}$ at $37^{\circ} \mathrm{C}$ in an atmosphere of $5-10 \%(\mathrm{v} / \mathrm{v}) \mathrm{CO}_{2}$. Cells were then removed from the filters by agitation in appropriate liquid medium and plated on either chocolate agar or nutrient agar suitably supplemented with antibiotics.

In triparental matings the combined number of primary donor and intermediate recipients was $10^{8}$ colony-forming units. In intergeneric crosses the ratio of $N$. gonorrhoeae or $H$. influenzae primary donors to $E$. coli intermediate recipients was approximately 10:1 in order to avoid overgrowth of the latter during overnight incubation. Transfer frequencies are expressed as transconjugants per colony-forming unit of initial donor at the onset of mating. In the biparental matings deoxyribonuclease I (Sigma) was added to a final concentration of $50 \mu \mathrm{g} \mathrm{ml}^{-1}$ to eliminate the possibility of plasmid transfer by transformation.

\section{RESULTS}

\section{Transfer of $p L V 10$ and $p L V 11$ from $N$. gonorrhoeae}

Our results from filter mating experiments (Table 2) confirmed the findings of others (Eisenstein et al., 1977; Roberts \& Falkow, 1977) that conjugative transfer of $\beta$-lactamase production in $N$. gonorrhoeae is dependent on the presence of a 24.5 megadalton plasmid. When residing in the same cell this plasmid mobilized pLV10 to other gonococci, to $H$. influenzae and to restriction-deficient $\left(h s d R_{\mathrm{k}}{ }^{-} M_{\mathrm{k}}{ }^{+}\right.$), but not restriction-proficient, strains of $E$. coli. In contrast, apart from some recent isolates from the Netherlands (J. van Embden, personal communication), all natural isolates of $N$. gonorrhoeae carrying the 3.2 megadalton $\beta$-lactamase plasmid (e.g. pLV11) lack the gonococcal sex factor and consequently did not transfer penicillin-resistance to other bacteria (Table 2). A triparental mating system was therefore used to establish the mobility of pLV11. Neisseria gonorrhoeae strain KH45, which carries only the plasmid pLE2451 (Elwell \& Falkow, 1977), could mobilize pLV11 from an intermediate donor strain of $N$. gonorrhoeae (1L261) to recipient bacteria of various species. Triparental matings were also successful for demonstrating mobilization of pLV10.

\section{Table 2. Transfer of penicillin resistance from $N$. gonorrhoeae to other bacteria}

\begin{tabular}{|c|c|c|c|c|}
\hline $\begin{array}{l}\text { Initial } \\
\text { donor }\end{array}$ & $\begin{array}{l}\text { Intermediate } \\
\text { donor }\end{array}$ & Recipient & $\begin{array}{l}\text { Transfer } \\
\text { frequency }\end{array}$ & $\begin{array}{l}\text { Plasmids in } \\
\text { transconjugants } \\
\text { (megadalton) }\end{array}$ \\
\hline $1 \mathrm{~L} 261$ & 一 & $N$. gonorrhoeae $1 \mathrm{~L} 403$ & $<10^{-8}$ & $2 \cdot 6$ \\
\hline $1 \mathrm{~L} 433$ & - & N. gonorrhoeae $1 \mathrm{~L} 403$ & $<10^{-8}$ & $2 \cdot 6$ \\
\hline $1 \mathrm{~L} 432$ & 一 & N. gonorrhoeae $1 \mathrm{~L} 403$ & $8 \times 10^{-4}$ & $\begin{array}{l}24 \cdot 5,4 \cdot 4,2 \cdot 6 \\
\text { or } 4 \cdot 4,2 \cdot 6\end{array}$ \\
\hline $1 \mathrm{~L} 432$ & 一 & E. coli $\mathrm{KH} 802$ & $1 \times 10^{-3}$ & 4.4 \\
\hline $1 \mathrm{~L} 432$ & - & E. coli UB 1005 & $<10^{-8}$ & - \\
\hline $1 L 432$ & - & H. influenzae UB2808 & $1 \times 10^{-4}$ & 4.4 \\
\hline KH45 & N. gonorrhoeae 1L261 & N. gonorrhoeae $1 \mathrm{~L} 403$ & $2 \times 10^{-4}$ & $\begin{array}{l}24 \cdot 5,3 \cdot 2,2 \cdot 6 \\
\text { or } 3 \cdot 2,2 \cdot 6\end{array}$ \\
\hline KH45 & N. gonorrhoeae 1L261 & E. coli KH802 & $1 \times 10^{-3}$ & $3 \cdot 2$ \\
\hline KH45 & N. gonorrhoeae $1 \mathrm{~L} 261$ & H. influenzae UB2808 & $4 \times 10^{-5}$ & $3 \cdot 2$ \\
\hline
\end{tabular}


Table 3. Ability of pLE2451, present in initial donor N. gonorrhoeae KH45, to mobilize $\beta$-lactamase plasmids pLV10 and pLV11 resident in E. coli or $H$. influenzae

Intermediate donor

E. coli KH802(pLV10)

E. coli $\mathrm{KH} 802(\mathrm{pLV} 11)$

E. coli $\mathrm{KH} 802(\mathrm{pLV} 10)$

E. coli UB 1005 (pLV10)

H. influenzae UB2806 (pLV 10)

H. influenzae UB2806(pLV10)

$H$. influenzae UB2806(pLV10)
Recipient

E. coli $\mathrm{UB} 1005$

E. coli UB 1005

N. gonorrhoeae $1 \mathrm{~L} 403$

E. coli $\mathrm{KH} 802$

H. influenzae UB2808

E. coli $\mathrm{KH} 802$

N. gonorrhoeae $1 \mathrm{~L} 403$
Transfer frequency

$$
\begin{aligned}
2 & \times 10^{-3} \\
5 & \times 10^{-4} \\
& <10^{-8} \\
& <10^{-8} \\
& <10^{-8} \\
& <10^{-8} \\
& <10^{-8}
\end{aligned}
$$

Approximately $50 \%$ of the penicillin-resistant transconjugant clones from either bi- or triparental intraspecific gonococcal matings were found by agarose gel electrophoresis to have acquired pLE245 1 in addition to the selected $\beta$-lactamase plasmid. Such clones were themselves capable of acting as donors of pLV10 or pLV11. This was in contrast to our observation of intergeneric crosses where transconjugants of $H$. influenzae and $E$. coli contained either pLV10 or pLV11 alone.

\section{Demonstration of transfer functions of pLE2451 in E. coli}

The absence of pLE2451 from transconjugants of certain species raised the question as to whether this plasmid was unable to enter these other bacterial species or whether it was so unstable as to be lost readily in the absence of direct selection pressure. A triparental system was used in order to distinguish these possibilities: it consisted of $N$. gonorrhoeae $\mathrm{KH} 45$ (carrying pLE2451) as primary donor, an $E$. coli $\left(h s d R_{\mathrm{k}}{ }^{-} M_{\mathrm{k}}{ }^{+}\right)$intermediate donor strain (KH802) carrying either pLV10 or pLV11, and a final recipient $h s d R_{\mathrm{k}}{ }^{+} M_{\mathrm{k}}{ }^{+}$strain of E. coli. The rationale of these experiments was such that entry of pLE2451 into the intermediate donor would be unimpeded by the restriction barrier and any DNA present in this donor would become modified for transfer to the final recipient. Table 3 shows that pLE2451 was able to mobilize both pLV10 and pLV11 between strains of $E$. coli so long as the restriction-deficient (KH802) and not the restriction-proficient (UB1005) strain was used as intermediate donor. No mobilization was detected if the final $E$. coli recipient was replaced by a recipient strain of $N$. gonorrhoeae. The probable reason for this became apparent when crude culture lysates of the recipient gonococcal strain 1 L403 were found to cleave pLV10 and pLV11 DNA propagated in $E$. coli or $H$. influenzae into several discrete fragments (data not shown). Cleavage patterns on plasmid and phage $\lambda$ DNA indicated that this strain, together with all other strains of $N$. gonorrhoeae used in this study (unpublished results), possesses the restriction endonuclease $\mathrm{NgoII}$ (Clanton et al., 1979).

The triparental mating technique was extended to include $H$. influenzae strains UB2806(pLV10) (Table 3) or UB2806(pLV11) (data not shown) as intermediate donors. Although strains of $H$. influenzae, $N$. gonorrhoeae and $E$. coli were all tested as final recipients in no case was there evidence of mobilization of the $\beta$-lactamase plasmids by pLE2451.

\section{Specificity of plasmid mobilization by pLE2451}

We have established that although pLE2451 was not stably maintained in $E$. coli, it was capable of mobilizing pLV10 and pLV11 resident in this host. It was therefore of some interest to determine whether the conjugative plasmid has the ability to mobilize non-conjugative plasmids originally derived from enteric bacteria or from Haemophilus species. For this purpose several small non-conjugative plasmids were separately transformed into the restriction-deficient $E$. coli strain $\mathrm{KH} 802$. The resulting plasmid-bearing lines were then used as intermediate donors in triparental matings. Certain plasmids originally isolated 
Table 4. Ability of pLE2451, present in initial donor N. gonorrhoeae KH45, to mobilize non-conjugative plasmids resident in E. coli KH802 to recipient E. coli UB1005

\begin{tabular}{l}
\multicolumn{1}{l}{ Intermediate donor } \\
KH802(ColE1.Tn501) \\
KH802(NTP5) \\
KH802(NTP1) \\
KH802(NTP16) \\
KH802(RSF0885) \\
KH802(pJB1)
\end{tabular}

Transfer frequency

$1 \times 10^{-4}$
$1 \times 10^{-3}$
$<10^{-8}$
$<10^{-8}$
$1 \times 10^{-4}$
$2 \times 10^{-3}$

from Enterobacteriaceae, e.g. NTP5 and ColE1.Tn501 were mobilized at a frequency similar to pLV10 (Table 4). In contrast NTP1 and NTP16, which also originated in enteric bacteria, were not mobilized. This is particularly interesting since like pLV10 and pLV11 these plasmids determine the production of TEM $\beta$-lactamase. However, two further $\beta$-lactamase plasmids, RSF0885, originally isolated from $H$. parainfluenzae (Roberts et al., 1977), and pJB 1, originally isolated from $H$. ducreyi (Brunton et al., 1979), were efficiently mobilized by pLE245 1 (Table 4).

\section{Lack of mobilization ability by $H$. influenzae conjugative plasmids}

Several conjugative $\mathrm{R}$ plasmids of 30-40 megadaltons have been isolated from strains of $H$. influenzae (Saunders et al., 1978). We were interested in determining whether or not there is a reciprocal relationship in plasmid mobilization between Neisseria and Haemophilus species which might account for the evolution of drug-resistance in these organisms. Accordingly, we studied the ability of three conjugative Haemophilus R plasmids, pRI234, pUB701 and pFR 16017, to mobilize $\beta$-lactamase plasmids present in intermediate donors. These plasmids were capable of transferring themselves between $H$. influenzae strains and to $E$. coli at a frequency of about $10^{-4}$. However, no mobilization of pLV10, pLV11, RSF0885 or pJB 1 was detected in either intraspecific $(H$. influenzae $\times H$. influenzae $\times H$. influenzae $)$ or intergeneric $(H$. influenzae $\times H$. influenzae $\times E$. coli or $H$. influenzae $\times E$. coli $\times E$. coli) matings with any of the three conjugative plasmids (data not shown).

\section{DISCUSSION}

Considerable clinical concern at the emergence of plasmid-mediated penicillin-resistance in $N$. gonorrhoeae has been heightened by demonstration of the conjugative properties of the 24. 5 megadalton gonococcal plasmids. Such plasmids have been shown to promote transfer of gonococcal $\beta$-lactamase plasmids to other strains of $N$. gonorrhoeae both in vitro (Eisenstein et al., 1977; Roberts et al., 1977; and this paper) and in vivo (Roberts \& Falkow, 1979). It is likely therefore that these 24.5 megadalton plasmids might play an important role in the evolution and spread of antibiotic resistance among pathogenic Neisseria. We have shown that one 24.5 megadalton plasmid, pLE2451, is highly efficient at mobilizing gonococcal $\beta$-lactamase plasmids, not only in intraspecific crosses but also in intergeneric crosses to $H$. influenzae or $E$. coli. Our results demonstrate that although pLE2451 fails to become established in $H$. influenzae or restriction-deficient $E$. coli, it does survive transiently in the latter genetic background long enough to express transfer functions necessary to mobilize resident plasmids. Transfer events involving transient vectors of this kind might be important in the wild, permitting penetration of resistance and other genes into gene pools and their subsequent dissemination in new host species. The failure of pLE2451 to promote transfer of pLV10 and pLV11 from $E$. coli or $H$. influenzae back into $N$. gonorrhoeae suggests that there is a considerable restriction barrier which limits gene flow in this direction. The relative rarity of such intergeneric transfer events would explain both the late acquisition 
of antibiotic resistance plasmids by the gonococcus and their limitation to two related plasmid species. Our results suggest therefore that transfer of genes promoted by pLE2451 occurs more readily out of the gonococcus gene pool to other genera than in the reverse direction. Indeed, Laufs et al. (1979) have speculated that pVe445, a 4.4 megadalton plasmid found in a strain of $H$. influenzae in West Germany, may have originated naturally by mobilization of an $N$. gonorrhoeae $\beta$-lactamase plasmid by a conjugative plasmid which was not itself maintained in Haemophilus. The relative facility with which gonococcal $\beta$-lactamase plasmids can be mobilized in vitro to $H$. influenzae might suggest that these bacteria have restriction-modification systems in common. Indeed, the two gonococcal restriction endonucleases described thus far, $\mathrm{NgoI}$ and $\mathrm{NgoII}$ (Clanton et al., 1979), are isoschizomers of HaeII and HaeIII, respectively, from H. aegyptius. The failure of pLE2451 to mobilize plasmids in the reverse direction might be explained if Haemophilus species restricted this plasmid. In addition, we have shown that recipient gonococci strongly restrict $\beta$-lactamase plasmids propagated in Haemophilus and other species. Despite such limitations on the intergeneric passage of pLE2451, this plasmid is capable of mobilizing indigenous Haemophilus non-conjugative plasmids, a property not found in conjugative plasmids isolated from this genus. Furthermore, pLE2451 is capable of efficient mobilization of several $\mathrm{R}$ plasmids originally isolated from enterobacteria. Roberts et al. (1979) found that about $15 \%$ of gonococcal strains isolated during the past 40 years harbour 24.5 megadalton plasmids. Our results demonstrate that these widely distributed plasmids are thus likely to play an important natural role in mobilizing plasmids across the species and generic boundaries between Neisseria and related Gram-negative bacteria.

This work was supported by a grant from the Medical Research Council (no. G976/811/S). We would like to thank P. Bennett, J. Brunton, S. Falkow, R. Laufs, A. Percival and J. Stuy for providing us with bacterial strains.

\section{REFERENCES}

Anderson, E. S., Threlfall, E. J., Carr, J., McConnell, M. \& Smith, H. R. (1977). Clonal distribution of resistance plasmid-carrying Salmonella typhimurium, mainly in the Middle East. Journal of Hygiene 72, 471-487.

Brown, M. G. M., Weston, A., Saunders, J. R. \& Humphreys, G. O. (1979). Transformation of Escherichia coli $\mathrm{C} 600$ by plasmid DNA at different phases of growth. FEMS Microbiology Letters 5, 219-222.

Brunton, J. L., Maclean, I., Ronald, A. R. \& Albritton, W. L. (1979). Plasmid-mediated ampicillin resistance in Haemophilus ducreyi. Antimicrobial Agents and Chemotherapy 15, 294-299.

Clanton, D. J., Riggsby, W. S. \& Miller, R. V. (1979). NgolI, a restriction endonuclease from Neisseria gonorrhoeae. Journal of Bacteriology 137, 1299-1307.

DAVIES, J. K. \& Normark, S. (1980). A relationship between plasmid structure, structural lability, and sensitivity to site-specific endonucleases in Neisseria gonorrhoeae. Molecular and General Genetics 177, 251-260.

Eisenstein, B. I., Sox, T., Biswas, G., Blackman, E. \& SPARLing, P. F. (1977). Conjugal transfer of the gonococcal penicillinase plasmid. Science 195, 9981000.

Elwell, L. P. \& Falkow, S. (1977). Plasmids of the genus Neisseria. In The Gonococcus, pp. 137-154. Edited by R. B. Roberts. New York: John Wiley.
ElWell, L. P., Roberts, M., Mayer, L. W. \& FALKow, S. (1977a). Plasmid-mediated betalactamase production in Neisseria gonorrhoeae. Antimicrobial Agents and Chemotherapy 11, 528533.

Elwell, L. P., Saunders, J. R., Richmond, M. H. \& FALKow, S. $(1977 b$ ). Relationships between some R-plasmids found in Haemophilus influenzae. Journal of Bacteriology 131, 356-362.

Grinsted, J., SAunders, J. R., INGRAM, L. C., SYKes, R. B. \& Richmond, M. H. (1972). Properties of an $\mathrm{R}$ factor which originated in Pseudomonas aeruginosa 1822. Journal of Bacteriology 110 , 529-537.

Kaulfers, P.-M., Laufs, R. \& Jahn, G. (1978). Molecular properties of transmissible $R$ factors of Haemophilus influenzae determining tetracycline resistance. Journal of General Microbiology 105, 243-252.

Laufs, R., Kaulfers, P.-M., JAHN, G. \& Teschner, U. (1979). Molecular characterization of a small Haemophilus influenzae plasmid specifying $\beta$ lactamase and its relationship to $R$ factors from Neisseria gonorrhoeae. Journal of General Microbiology 111, 223-231.

MAyeR, L. W., Holmes, K. K. \& Falkow, S. (1974). Characterization of plasmid deoxyribonucleic acid from Neisseria gonorrhoeae. Infection and Immunity 10, 712-717. 
Meyers, J. A., Sanchez, D., Elwell, L. P. \& FALKow, S. (1976). Simple agarose gel electrophoretic method for the identification and characterization of plasmid deoxyribonucleic acid. Journal of Bacteriology 127, 1529-1537.

ROBERTS, M. \& FALKow, S. (1977). Conjugal transfer of $\mathbf{R}$ plasmids in Neisseria gonorrhoeae. Nature, London 266, 630-631.

ROBERTS, M. \& FALKow, S. (1979). In vivo conjugal transfer of $\mathrm{R}$ plasmids in Neisseria gonorrhoeae. Infection and Immunity 24, 982-984.

Roberts, M., Elwell, L. P. \& Falkow, S. (1977). Molecular characterization of two beta-lactamasespecifying plasmids isolated from Neisseria gonorrhoeae. Journal of Bacteriology 131, 557-563.

Roberts, M., Piot, P. \& Falkow, S. (1979). The ecology of gonococcal plasmids. Journal of General Microbiology 114, 491-494.

Saunders, J. R., Elwell, L. P., Falkow, S., Sykes, R. B. \& RichmoND, M. H. (1978). $\beta$-Lactamases and $\mathrm{R}$ plasmids of Haemophilus influenzae. Scandinavian Journal of Infectious Diseases, Suppl. 13, 16-22.

SmITH, H. R., Humphreys, G. O. \& ANDERson, E. S. (1974). Genetic and molecular characterization of some non-transferring plasmids. Molecular and General Genetics 129, 229-242.
Sox, T. E., Mohammed, W., Blackman, E., Biswas, G. \& SPARLiNG, P. F. (1978). Conjugative plasmids in Neisseria gonorrhoeae. Journal of Bacteriology 134, 278-286.

Sparling, P. F., Sox, T. E., Mohammed, W. \& GuYman, L. F. (1978). Antibiotic resistance in the gonococcus: diverse mechanisms of coping with a hostile environment. In Immunobiology of Neisseria gonorrhoeae, pp. 44-52. Edited by G. F. Brooks, E. C. Gotschlich, K. K. Holmes, W. D. Sawyer \& F. E. Young. Washington: American Society for Microbiology.

Tenover, F. C., Mayer, L. W. \& Young, F. E. (1980). Physical map of the conjugal plasmid of Neisseria gonorrhoeae. Infection and Immunity 29, 181-185.

van Klingeren, B., van Embden, J. \& DessensKroON, M. (1977). Plasmid-mediated chloramphenicol resistance in Haemophilus influenzae. Antimicrobial Agents and Chemotherapy 11, 383-387.

WooD, W. B. (1966). Host specificity of DNA produced by Escherichia coli: bacterial mutations affecting the restriction and modification of DNA. Journal of Molecular Biology 16, 118-133. 